\title{
THE GLACIERS OF JAN MAYEN
}

\author{
By D. J. J. Kinsman \\ (Department of Geology, Imperial College, London) \\ and J. W. Sheard \\ (Department of Botany, Imperial College, London)
}

\begin{abstract}
A descriptive account of the glaciers of Jan Mayen is given, based on the results of two recent University of London expeditions. The positions of most of the glacier snouts are compared with previous records and a general advance of the ice margin is reported. The discovery of massive tillite deposits low down in the volcanic sequence is thought to confirm the post-Pleistocene origin of the present Beerenberg mountain. An outline of the geological and topographical evolution of the mountain is related to the history of its glaciation. Three major advances of the ice margin are described, the most recent having taken place within the last 350 years. The transient nature of high-altitude rime structures is demonstrated.
\end{abstract}

RÉsumé. Un compte-rendu descriptif des glaciers de Jan Mayen est donné, à partir des résultats de deux expéditions récentes de l'Université de Londres. Les positions de la plupart des langues glaciaires comparées avec des observations antérieures montrent une avance générale de la bordure de la glace. Il semble que la découverte de depôts de tillite massive à la base de la série volcanique confirme l'origine post-Pléistocène de l'actuel mont Beerenberg. Une esquisse de l'évolution géologique et topographique de la montagne est reliée à l'histoire de ses glaciations. Trois importantes avances de la bordure de la glace sont décrites, la plus récente ayant pris place dans les dernières 350 années. On démontre la nature transitoire des structures de givre de haute-altitude.

Zusammenfassung. Auf der Grundlage der Ergebnisse zweier neuerlicher Expeditionen der University of London wird eine beschreibende Darstellung der Gletscher von Jan Mayen gegeben. Die Lage der meisten Gletscherzungen lässt sich mit früheren Berichten vergleichen, woraus ein allgemeiner Vorstoss des Eisrandes zu folgern ist. Die Entdeckung massiver Tillit-Ablagerungen am unteren Ende der vulkanischen Schichtenfolge scheint die nach-pleistozäne Entstehung des heutigen Beerenbergs zu bestätigen. Die geologische und topographische Entwicklung des Berges lässt sich umrisshaft mit der Geschichte seiner Vergletscherung verknüpfen. Es werden 3 grössere Vorstösse des Eisrandes beschrieben, deren letzter innerhalb der letzten 350 Jahre stattfand. Die Flüchtigkeit von Reif-Strukturen in grosser Höhe wird nachgewiesen.

\section{INTRODUCTION}

The Imperial College of Science Expedition to Jan Mayen in $193^{8}$ (King, I939) made the first survey of the glaciers of Nord Jan. Jennings (1939, 1948) reported a general retreat of the glaciers, the latter paper remaining the standard work on the glaciers of Jan Mayen. Aerial photographs of the glaciers were taken by the Norsk Polarinstitutt in the course of making surveys for its map (scale $\mathrm{I}: 50,000$ ) which was published in $\mathrm{r} 959$. The vertical and oblique photographs which were flown in 1949 are now available for the whole island.

The University of London Jan Mayen Expedition, I959 (Smith, unpublished) reported an advance of Sørbreen and presented evidence indicating that this was part of a general advance affecting the glaciers of Beerenberg. These findings have been substantiated by the 1961 University of London Beerenberg Expedition (Fitch and others, 1962) and correlated with the trend of increasing precipitation recorded since the meteorological station was established on the island in $192 \mathrm{I}$. A more detailed investigation of the climatological factors affecting Jan Mayen has been made by Lamb and others (1962).

\section{The State of the Ice Margin in ig6i}

It was originally hoped that a detailed ground survey of all the glaciers of Beerenberg would be made during the 196 i expedition. Unfortunately much of the glaciological programme had to be abandoned following the tragic loss of the glaciological party in a small boat accident. Nevertheless, an almost complete survey of the glacier snouts was made during the geological mapping programme and the coastal surveys carried out from the expedition supply ship. The photographs obtained on these surveys show very clearly that an advance has taken place since the aerial photographs were flown in r949. The positions 
quoted for the glacier snouts should be regarded as good approximations to their true positions. A map of the Nord Jan glaciers is given in Figure $\mathrm{I}$.

The Glaciers of the East Coast

Willebreen, Clarkebreen (collectively the "Wille Glacier" of Jennings (1948)) and Prins Haralds Breen terminate in the sea as they did in r 938 and 1949. Any variation in the activity of these glaciers could only be found by detailed ground investigation.

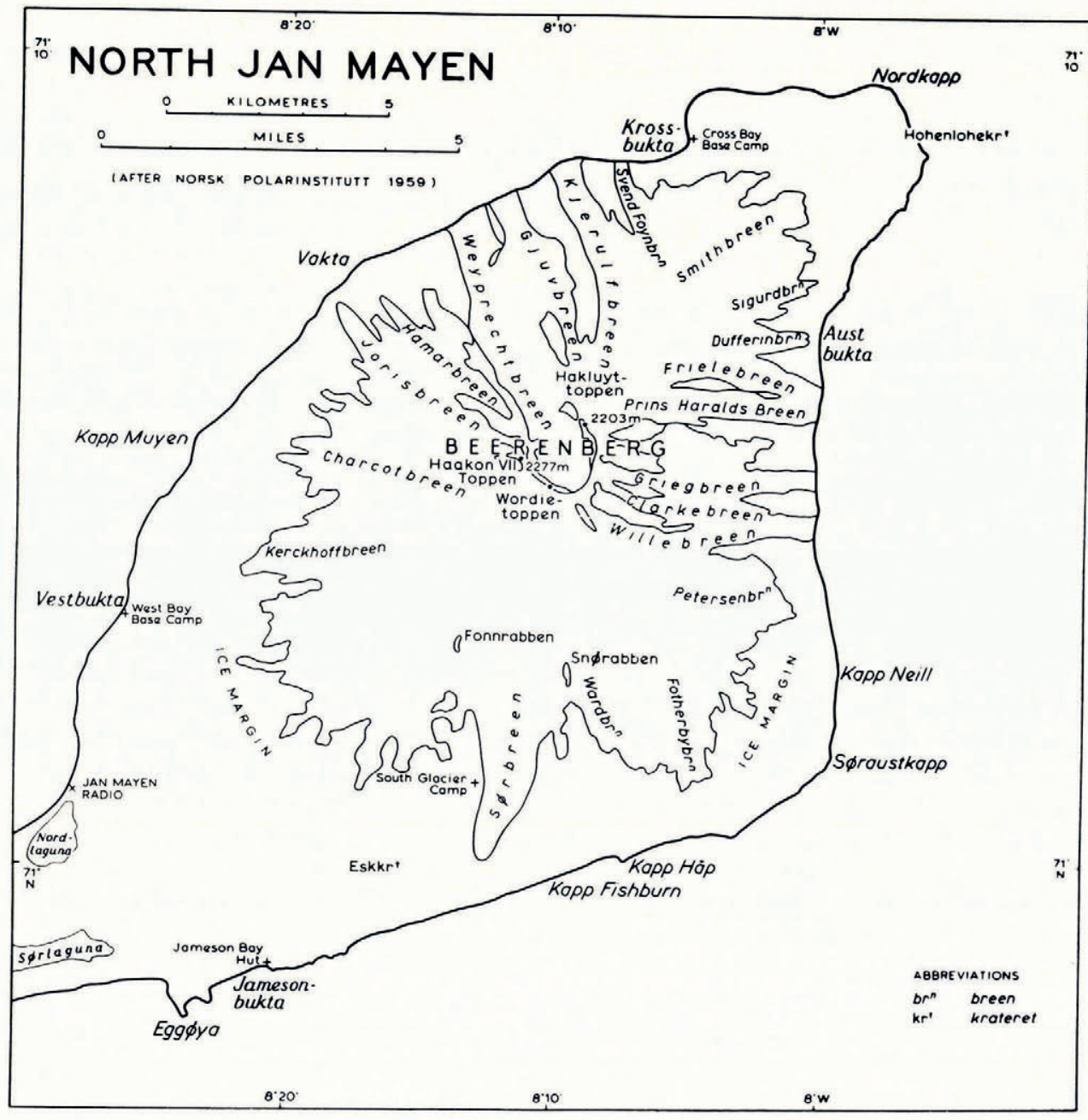

Fig. I. Map of Nord Jan showing the Beerenberg ice field and glacier system

Petersenbreen now has a lobed snout and, although photographs do not allow its position to be assessed, the nature of the snout and its severe crevassing suggest that it may be advancing.

Griegbreen was reported as reaching the sea in 1938 but the snout was not attached to the main body of the glacier. By 1949 the snout had retreated up the cliffs to an altitude of $60 \mathrm{~m}$. Photographs taken in 1959 show that the glacier had advanced to the coast and the snout now terminates in an actively calving ice front. 
Frielebreen also terminates in the sea with an active ice cliff, as it did in 1959. Below the 240 $\mathrm{m}$. contour this glacier is joined by Prins Haralds Breen and these two glaciers were together called the "Friele Glacier" by the 1938 expedition. The northern part of the latter glacier (now Frielebreen) had no ice cliff in 1938 and it terminated some distance behind the shoreline. Its position in I949 appears to have been much the same as it was in 1938 .

Dufferinbreen was reported to terminate ${ }_{1} 5^{2} \mathrm{~m}$. up in the cliffs in $193^{8}$. By 1949 the retreat had continued to an altitude of about $250 \mathrm{~m}$., large areas of dead ice being left behind. Photographs now show that the glacier is advancing down the cliffs in two lobes, the northern lobe overriding the remnants of the dead ice. The snout is now at an altitude of $200 \mathrm{~m}$.

Sigurdbreen was retreating from the ice-cored moraines at the foot of the cliffs in 1938. A rapid retreat must have followed as the snout was at an altitude of $300 \mathrm{~m}$. in 1949 . A small advance to $260 \mathrm{~m}$. has taken place since that time and the glacier snout shows the characteristic features of an advancing glacier. There is some evidence that the unnamed ice tongue immediately north of Sigurdbreen is also advancing.

Smithbreen. This glacier in the extreme north-east has been named after Peter Smith who was responsible for the glaciological programmes of the 1959 and r $_{9}$ I $_{\mathrm{r}}$ expeditions. This name has been approved by the Norsk Polarinstitutt. The main interest in this glacier lies in its well-preserved outer moraines-Moraine I (p. 444). The terminal moraine of this system lies at the foot of the old cliff line on the coastal lava platform. Jennings (1948) did not comment on this glacier and there is no evidence to suggest that an advance is taking place here.

\section{The Glaciers of the North Coast}

Svend Foynbreen, Kjerulfbreen and Weyprechtbreen have always been reported as the most active glaciers of Beerenberg. They have a convex cross-section at their snouts and show no signs of a recent lowering in the level of their snouts (Jennings, I948).

Svend Foynbreen. In $193^{8}$ Jennings commented that there was a beach exposed below the terminal cliff of the glacier at most stages of the tide, although active calving was in progress. The glacier is shown on the Norwegian map as terminating just behind the beach in I 949 . In 1959 and I96r, however, the base of the glacier was only exposed at low tide and nothing that could be described as a beach was seen. It is interesting to note that this is the only glacier on the island which forms ogives.

Kjerulfbreen is the only glacier of comparable size to Weyprechtbreen. These two glaciers are of particular interest because of the presence of massive outwash fans around their snouts. Both fans when viewed from their seaward margins are seen to be well bedded.

Gjuvbreen. Jennings (I948) referred to this glacier as the "East Weyprecht Glacier" and reported it as terminating in an ice fall behind the cliff line. Its position, very approximately, must have been $\mathrm{I}, 000 \mathrm{~m}$. from the sea. The Norwegian map shows the snout to be $450 \mathrm{~m}$. short of the coastline. This advance continued after 1949 and the glacier now ends in a dirty ice cliff on the coast. It is worth noting that in 196 i the snout was far less dirty than it was in I959 when in the same position. This glacier has a lower accumulation area than the other glaciers of Beerenberg (Fig. 2) and shifts of the firn line must therefore have a relatively greater effect on the regime of this glacier. This may be the cause of the present readvance having started before I 949 .

Weyprechtbreen is by far the most spectacular of all the Jan Mayen glaciers (Fig. 2). The wide breach in the crater rim through which the ice field is drained was thought by Jennings to be due to a violent volcanic explosion. Wordie (1926) considered that it might have been formed as a final run-out channel like those which many of the small parasitic cones exhibit. There is no evidence for either of these postulations and it is just as likely that Weyprechtbreen itself was largely responsible for the breaching of the crater wall. The corries of the east coast glaciers are almost breaching the eastern wall of the crater. 
The Glaciers of the North-west Coast

Hamarbreen. Jennings (1948) did not comment on this glacier except to report that the presence of moraines to the south of Weyprechtbreen indicated former glacier activity there. His map, however, shows an ice tongue which can only correspond to Hamarbreen. The Norwegian map shows the glacier to be $1,300 \mathrm{~m}$. from the sea. In 1959 Smith (unpublished) reported that "the ice margin seems to be more definite than that marked on the map". This first suspicion of an advance has been confirmed by the photographs taken in r 96 I which

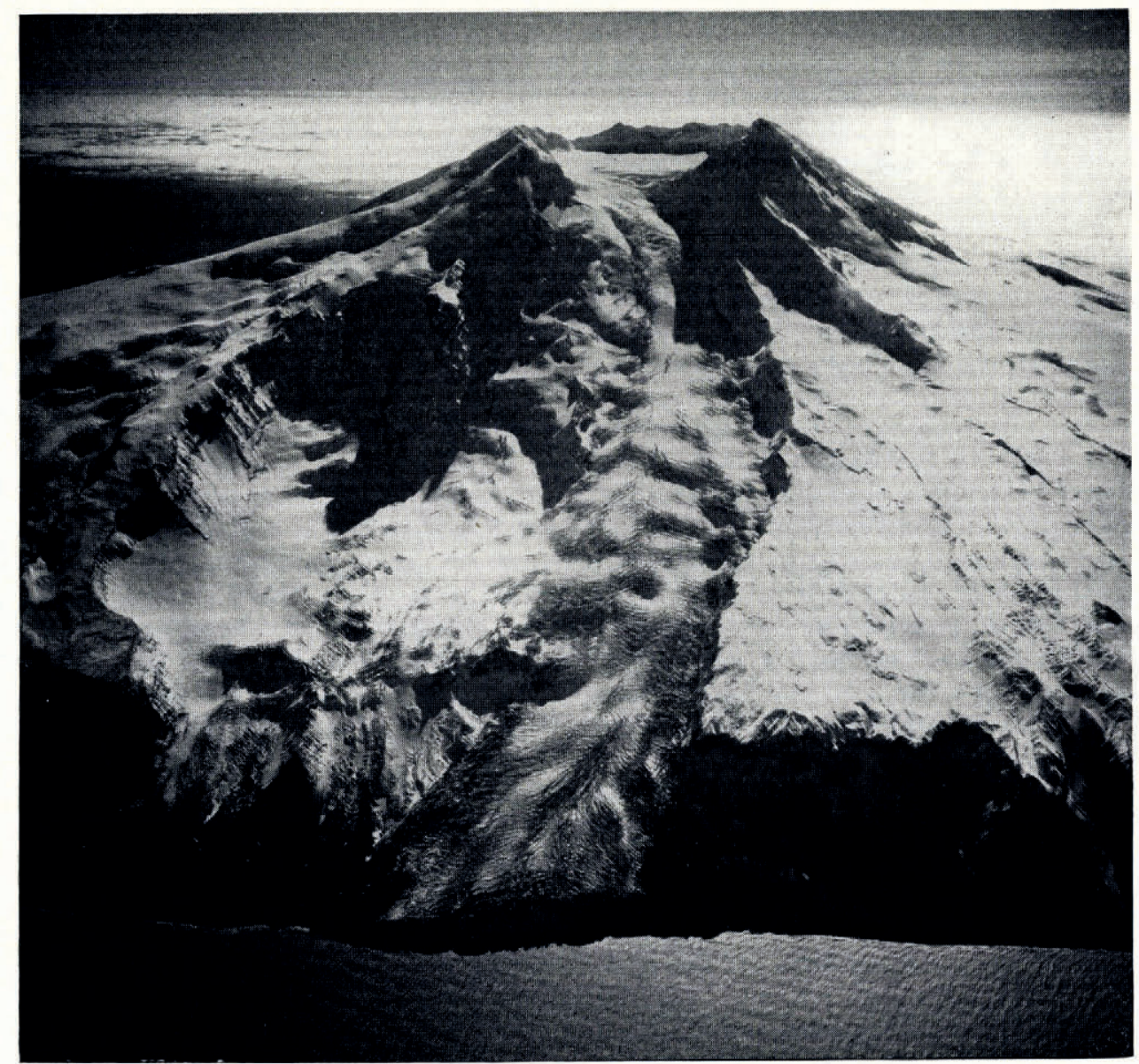

Fig. 2. Weyprechtbreen from the north in 1949. Gjuvbreen is the glacier on the left of the photograph; Hamarbreen, near the top of the cliffs, is on the right. Moraines of the Krogness Advance can be seen on the flanks of the mountain immediately to the west of Weyprechtbreen. Note also the summit cone and crater of Beerenberg sitting on the basal dome of the mountain. Photograph by kind permission of the Norsk Polarinstitutt

show that the snout had reached the top of the cliffs, $875 \mathrm{~m}$. from the coastline. Very fresh lateral moraines on the southern margin of the glacier are evidence of greatly increased activity.

forisbreen shows one of the most spectacular advances on the island. Jennings (1948) reported the glacier as being in strong retreat, with large gaps noticeable in the ice fall above its snout. By 1949 the glacier had retreated beyond the top of the cliffs to an altitude of $300 \mathrm{~m}$. In 1959 the snout was observed to be half way down the cliffs at an altitude of $100 \mathrm{~m}$. By I96 I 
the snout had reached the base of the cliffs $50 \mathrm{~m}$. above sea-level and $150 \mathrm{~m}$. from the shore, but still inside the most recent moraines.

Charcotbreen. Jennings ( 1948 ) reported that this glacier was more active in 1938 than either Sørbreen or Fotherbybreen. The terminal ice cliff was $180 \mathrm{~m}$. from the coast and this distance had increased greatly by 1949 . The amount of debris on the glacier at this time makes it impossible to distinguish the true position of the snout in the terminal moraine. It was not possible to plot the position of the snout in I96 I but a photograph higher up the glacier shows it is convex in cross-section which may indicate that it is in an active state.

Kerckhoffbreen. Previous positions of the glacier snout are more difficult to determine than for Charcotbreen. In $193^{8}$ the glacier surface near the snout was very flat, whereas it is now bulging and the glacier surface behind it is severely crevassed. There is little doubt that the glacier is now in an active state and it is almost certainly advancing. This glacier possesses

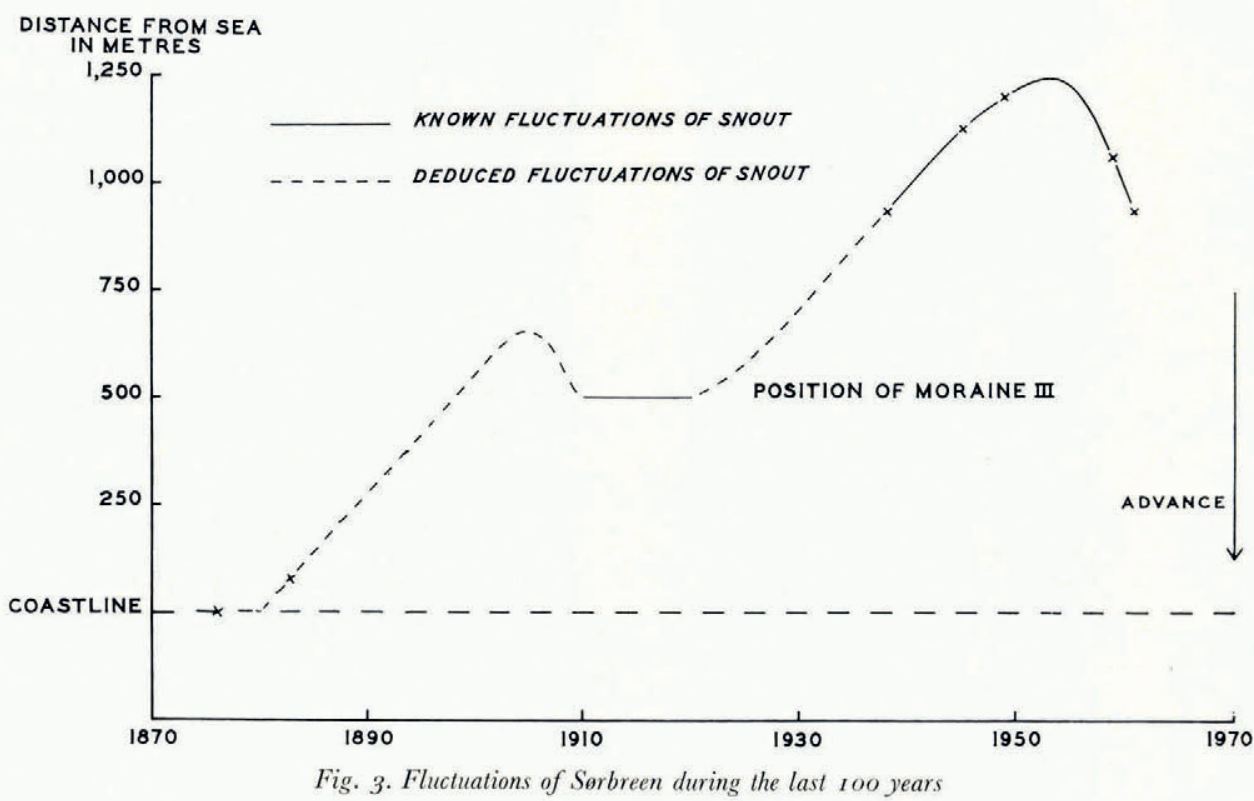

the most perfect moraine sequence of all the glaciers on Jan Mayen. Like Smithbreen, the oldest moraines of the series were deposited on land. These moraines were described in detail by the Austrian Polar Year Expedition (Boldva, i 886).

\section{The Glaciers of the South Coast}

Neither the 1959 nor 196 I expeditions have any information regarding the activity of either Fotherbybreen or Wardbreen.

Sorbreen has been studied intensively by these expeditions and by previous expeditions. The fluctuations of this glacier have been fully considered by Fitch and others (1962) and only a diagram of the fluctuations (Fig. 3) need be presented here. (Table I in the paper by Lamb and others (1962) gives the known positions on which this curve is based.) A photograph of the advancing snout of Sørbreen taken in I959 is shown in Figure 4.

\section{The Modern Moraine Systems}

By examining the different series of moraines Jennings (I948) was led to suggest that the retreat of the glaciers observed by the $193^{8}$ expedition had taken place in two main 
stages. The first stage was characterized by the extensive hummocky moraines found outside Kerckhoffbreen and the unnamed glacier to the south, and by the massive moraines at the foot of Weyprechtbreen. The retreat of the ice margin inside these moraines took place before the visit of the Austrian Polar Year Expedition of I882-83. The second stage of the retreat was characterized by two sets of terminal moraines which were observed for most of the glaciers not terminating in the sea. This retreat was considered to have been rapid as there was little accumulation of morainic debris between the inner and outer ridges.

These complex series of moraines are believed to have been formed following advances in approximately $175^{\circ}$, $185^{\circ}-70$ and $1910-20$, and have been termed Moraines I, II and III respectively (Fitch and others, 1962). In this the authors agree with Thorarinsson (1940) when he refers the second phase of the recent ice retreat to the period after the "Hochstand" in the middle or latter half of the nineteenth century, and the outermost moraine ridges to an

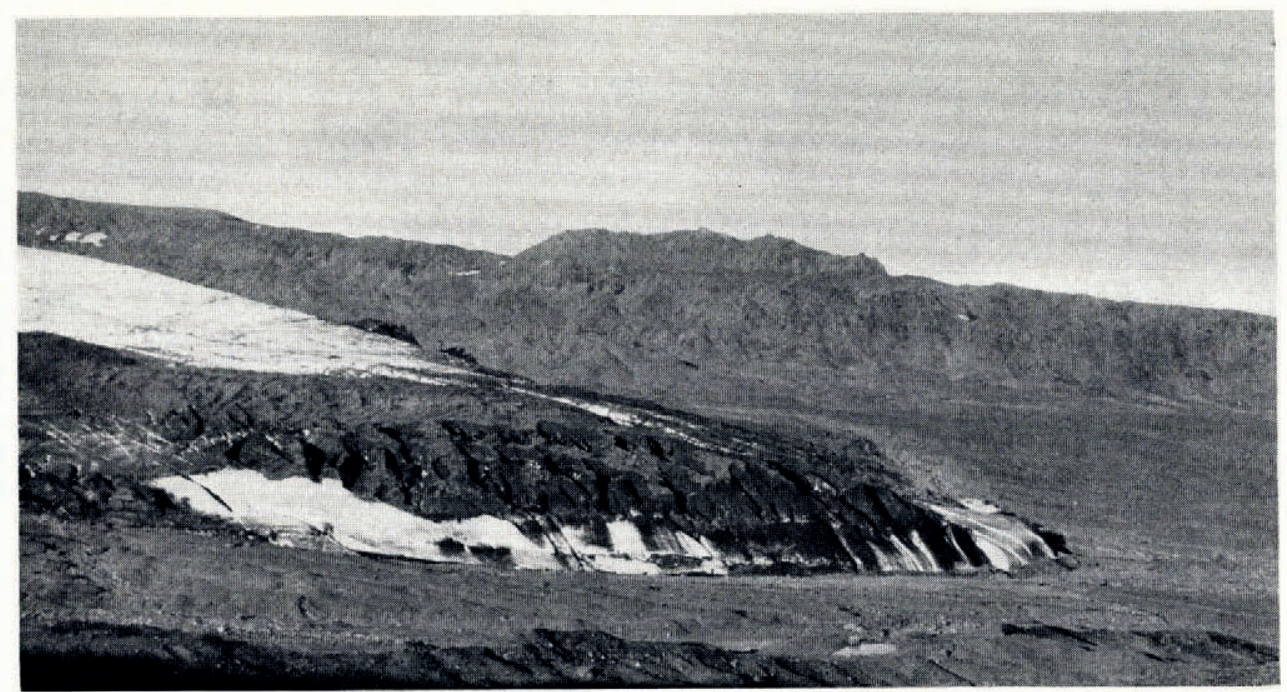

Fig. 4. The snout of Sorbreen in I959 from the west lateral moraine. Note the high lateral moraine (Moraine I) on far side of valley. Photograph by B. Chadwick

advance culminating in the middle of the eighteenth century. Careful study of aerial photographs shows that the extensive hummocky moraines already noted between Moraines I and II at Kerckhoffbreen are present, in other places, as one or more distinct ridges and it seems probable that the retreat between $175^{\circ}$ and $185^{\circ}$ was both slow and oscillatory. This whole period has been termed the Sørbreen Advance.

\section{Rime Accumulation at High Altitude}

Brief mention must be made of the great rime accumulations which are to be seen around the crater rim. Russell (1939) has given an account of the rime in his description of the Beerenberg mountain. The massive rime dome forming the summit of Haakon VII Toppen is probably the best example of the many rime domes which cap rock outcrops around the crater rim. Members of the 1938 expedition succeeded in surmounting this obstacle but it proved impossible to climb in both 1959 and I96r. A comparison of photographs taken in 1938 and 1959 shows that its diameter increased by about five times during this period. In $\mathrm{r} 959$ it was approximately $5^{\circ} \mathrm{ft} .(15 \cdot 2 \mathrm{~m}$.) in diameter and had the appearance of a gigantic 
mushroom. In 1961 much of this dome was found to have collapsed, as is shown by comparing Figures $5 \mathrm{a}$ and $5 \mathrm{~b}$.

\section{The Evolution of Beerenberg and its Ice Fields}

In this section a brief outline of the geological and geomorphological history of Nord Jan is given, to show the basis on which the glaciological history of the mountain is built. The chronology follows that of Fitch (in press) but it is to be regarded with some caution. Further detailed field work is still required so that several outstanding problems which have an important bearing on any chronology may be investigated.

The discovery of a massive double tillite deposit low down in the volcanic succession at Kapp Fishburn indicates that there was extensive glaciation of the proto-Beerenberg at some period. The lower of the two tillites has been tentatively correlated with the Fennoscandinavian
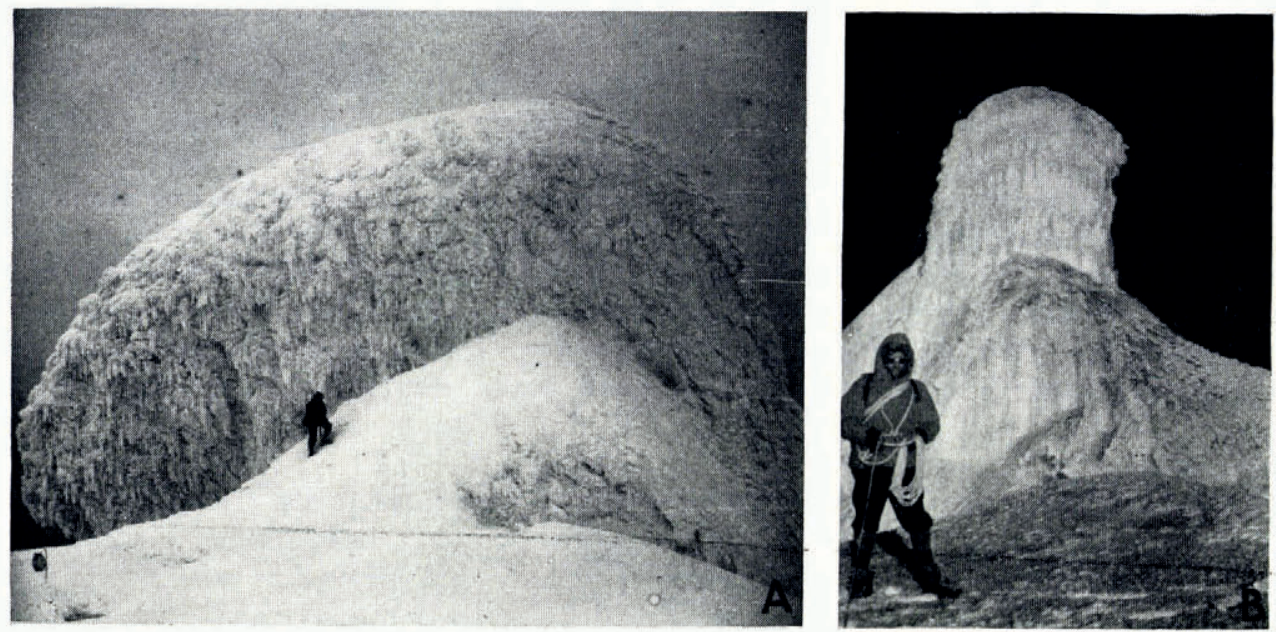

Fig. 5. Summit rime dome of Haakon VII Toppen in (a) 1959 and $(b) 196 r$. Note the stratification of the rime in (b). Photograph $(a)$ by R. G. Wright and $(b)$ by D. F. J. Kinsman

moraines of about 12,000 yr. B.P. It should be emphasized that if this assumption is proved to be incorrect then the dating of much of the sequence which follows must also be incorrect. Fitch has suggested that the upper tillite may be of Younger Dryas age (I0,000-10,500 B.P.). There is no evidence of another major glaciation later in the volcanic sequence nor is there at present any direct evidence which might weigh against this assumption.

During the major glaciation the proto-Eeerenberg was probably a simple dome. The deposition of the tillites was followed by a series of volcanic eruptions from the central sink, building the basal dome to almost its present height and form. Throughout this whole period there is no evidence of any glacial activity.

After a period of erosion the volcano entered a new cycle of activity which resulted in the formation of the summit cone and crater between 6000 and 7000 B.P. It seems likely that from this time onwards at least the summit of the mountain has borne a permanent snow cover and that the formation of corries also dates from this time. This period of volcanic activity occurred during the post-glacial climatic optimum when sea-level was rising rapidly and eroding the huge cliffs of the north and east coasts.

Shortly after the summit cone and crater of Beerenberg had formed, fissure volcanism (the Tromsøryggen period of activity) commenced on the east and west flanks of the mountain. In the north-east lavas poured over the sea cliffs pushing the coastline seawards. No pillow 
lavas are visible in the modern sea cliffs cut into these lavas, therefore at the time of their eruption sea-level must have been relatively lower than it is at present; how much lower depends on the thickness of the normal sub-aerially erupted lavas now below sea-level.

Godwin and others (1958) have shown that sea-level had largely re-established itself by $55^{00}$ B.P. Godwin (1940) had previously shown that after reaching a maximum height in $3500-4000$ B.P. sea-level temporarily receded below its present level. The Tromsøryggen lavas could therefore have been extruded either prior to 5500 B.P. or at some time after that date when the sea was below its present level. Fitch favours the thesis that this volcanism occurred after a minor rise of sea-level before the post-Pleistocene maximum, and dates the activity between 4000 and 5000 yr. B.P.

After the Tromsøryggen activity an extensive advance of the Beerenberg ice field occurred and broad ice tongues extended to the tops of the cliffs. It can be seen from the moraines lying on top of the cliffs of Weyprechtbreen that the glaciers had not yet begun to cut the valleys which they now occupy. The moraines of this, the Krogness Advance, are conspicuous in the aerial photographs of the north-west flanks of the mountain, forming great petal-like features around, but not directly associated with, the present-day glaciers. It is interesting to note that Beschel ( $196 \mathrm{I}$ ) has suggested a comparable advance of the Greenland glaciers in about 4000 B.P.

Following the formation of these moraines came another cycle of fissure eruption. These lava flows - the Koksletta lavas - can be seen flowing round and burying the moraines of the Krogness Advance. The Koksletta lavas poured over the high cliffs and onto the lava platforms of the previous eruption before finally reaching the sea. This activity determines the present-day shore-line in some parts of the island. The lava flows buried a marine platform and raised beach cut into the Tromsøryggen lavas at the time of the maximum advance of the post-Pleistocene sea. The Koksletta lavas therefore post-date the raised beach which is at a height of 8-10 $\mathrm{m}$.

Other features of the coastal topography which are of interest are the outwash fans of Kjerulfbreen and Weyprechtbreen. These are thought to have been formed under climatic conditions different from those of the present-probably more pluvial in nature. The lateral extent of the fans indicates that they were formed when the parent glaciers were still cutting their valleys high up in the cliffs and also at a time when sea-level was somewhat below that at present.

There is evidence at Sørbreen (Flint, I948), Jorisbreen, Hamarbreen and Smithbreen of a further advance of the glaciers post-dating the Koksletta eruptions but occurring an appreciable time before the Sørbreen Advance. Where they are visible the moraines of this advance, which has been termed the Joris Advance, appear outside the more recent deposits as muchdegraded material. The later advance of the glaciers was more extensive and broke through these moraines, so that in general they have not been well preserved. It is possible that this advance of the glaciers can be compared with that of some of the Scandanavian glaciers known to have taken place at about 2500 B.P. (Ahlmann, 1953).

In other areas a period of favourable climate followed in A.D. 0-40o. Fitch (in press) has correlated a $5 \mathrm{~m}$. raised beach on the island with this period. The latest events in the history of Nord Jan are then, the Joris Advance, a minor trangression of the sea to form the $5 \mathrm{~m}$. raised beach and the Sørbreen Advance which has been previously discussed and which is closely correlated with the "Little Ice Age" of the last $35^{\circ} \mathrm{yr}$.

\section{Discussion}

Evidence of three post-Pleistocene glacier stands on Jan Mayen has been presented. The first of these, the Krogness Advance, is thought to have occurred about 4000 B.P.; the second, the Joris Advance, at about 2500 B.P.; and the third or Sørbreen Advance has taken place during the last $35^{\circ} \mathrm{yr}$. and is still running its course. The latter two stands are well known and 
seem to be characteristic features of most glaciated areas, in the Northern Hemisphere at least. The Krogness Advance is of greater interest. It occurred towards the end of the postglacial climatic optimum and may have been the most extensive advance of the ice margin that has taken place on the present Beerenberg mountain. The anomalous situation of a major advance of the Jan Mayen glaciers during a time of favourable climate therefore appears to exist.

It is interesting to consider the Krogness Advance in the light of our knowledge of the most recent fluctuations of the glaciers. Since 1900 two minor advances of the glaciers have occurred during a period of generally mild climate. These two advances have been associated with times of high-intensity atmospheric circulation, the period from 192 I onwards being associated with an increase in precipitation of almost $\mathrm{I}$ oo per cent on Jan Mayen. It is tempting to suggest that a similar circulation pattern might have existed at the time of the Krogness Advance, and that the accompanying high level of precipitation induced an advance of the glaciers. Such a direct correlation, however, should be considered with extreme caution until more conclusive information is forthcoming.

Glacial advances in other regions comparable with the Joris and Sørbreen Advances are known to have been associated with depressed temperatures. It would seem, therefore, that the glaciers of Jan Mayen respond positively to two extremes of climate: to times of both high and low temperatures. The possibility of this having occurred in other areas of the world should be considered.

It is hoped that another expedition to Jan Mayen in 1963 will be able to produce further information concerning the chronological sequences and glaciological history of Jan Mayen. The programme will also include a redetermination of the positions of the glacier snouts and an extended programme of measurements on Sørbreen.

\section{Acknowledgements}

The authors wish to acknowledge the work of the late J. D. Booth, J. F. Cole, J. R. Fraser, C. M. Smith and P. Smith, members of the first glaciological party, who lost their lives during the r96r expedition, and in particular the hard work and enthusiasm of Peter Smith who was responsible for the glaciological programmes of both the recent expeditions. We should also like to thank the other members of the 1959 glaciological team and the geologists of the 196r expedition for their assistance in the field. We are grateful to F. J. Fitch, leader of the I96r expedition, for his helpful criticism during the preparation of this paper.

The two expeditions have received considerable assistance from the D.S.I.R., the Royal Society, the University of London, the Mount Everest Foundation, N.A.T.O., the Royal Geographical Society, the Norsk Polarinstitutt, and many other private individuals and commercial firms, to whom sincere thanks are offered.

MS. received 6 July 1962

\section{REFERE NCES}

Ahlmann, H. W. 1953. Glacier variations and climatic fluctuations. New York, American Geographical Society. (Bowman Memorial Lectures, Series 3.)

Beschel, R. E. I96r. Dating rock surfaces by lichen growth and its application to glaciology and physiography (lichenometry). (In Raasch, G.O., ed. Geology of the Arctic. Toronto, University of Toronto Press, Vol. 2, p. 1044 62.

Boldva, A. B. von. I886. Aufnahme und Beschreibung der Insel Jan Mayen. Beobachtungen über Gletscherbewegung. Die Oesterreichische Polarstation Jan Mayen: Beobachtungs-Ergebnisse (Wien), Bd. I, p. 27-50.

Fitch, F. J. In press. The development of the Beerenberg volcano. Proceedings of the Geslogists' Association.

Fitch, F. J., and others. 1962. Glacier re-advance on Jan Mayen, by F. J. Fitch, D. J. J. Kinsman, J. W. Sheard and D. Thomas. Union Géodésique et Géophysique Internationale. Association Internationale d'Hydrologie Scientifique. Colloque d'Obergurgl, $10-9-18-9$ 1962, p. 201-11. 
Flint, R. F. 1948. Glacial geology and geomorphology. (In Boyd, L. A., and others. The coast of northeast Greenland, with hydrographic studies in the Greenland Sea. The Louise A. Boyd Arctic expeditions of 1937 and $193^{8}$. American Geographical Society, Special Publication No. 30, p. 91-210.)

Godwin, H. r940. Studies of the post-glacial history of British vegetation. Part III. Fenland pollen diagrams. Part IV. Post-glacial changes of relative land- and sea-level in the English fenland. Philosophical Transactions of the Royal Society, Ser. B, Vol. 230, No. 570, p. 239-303.

Godwin, H., and others. 1958. Radiocarbon dating of eustatic rise in ocean-level, by H. Godwin, R. P. Suggate and E. H. Willis. Nature, Vol. I81, No. 4622, p. I518-19.

Jennings, J. N. 1939. Appendix II. (In King, I 939, p. г 28-31.)

Jennings, J. N. I948. Glacier retreat in Jan Mayen. Journal of Glaciology, Vol. I, No. 4, p. I67-71, I 78-81.

King, A. 1939. The Imperial College Expedition to Jan Mayen Island. Geographical fournal, Vol. 94, No. 2, p. I I 5-

Lamb, H. H., and others. 1962. A new advance of the Jan Mayen glaciers and a remarkable increase of precipitation, by H. H. Lamb, J. R. Probert-Jones and J. W. Sheard. Journal of Glaciology, Vol. 4, No. 33, p. 355-65.

Russell, R. S. 1939. The Beerenberg, Jan Mayen. Alpine Journal, Vol. 51, No. 258, p. 18-28.

Smith, P. Unpublished. Final report, Imperial College section, University of London Jan Mayen Expedition

r959.
Thorarinsson, S. 1940. Present glacier shrinkage and eustatic changes of sea level. Geografiska Annaler, Årg. 22, Ht. $3-4$, p. I $31-59$.

Wordie, J. M. 1926. The geology of Jan Mayen. Transactions of the Royal Society of Edinburgh, Vol. 54, Pt. 3, No. 18 , p. $74 \mathrm{I}-45$. 